\title{
8 Maarit Verronen's Monomaniacs of the Anthropocene
}

\author{
Scaling the Nonhuman in \\ Contemporary Finnish Fiction
}

\author{
Sarianna Kankkunen
}

In Luolavuodet ("The Cave Years"), a novel by Maarit Verronen, a team of speleologists explores an underground passageway. It is a long walk along the ancient subterranean riverbed, and since the terrain is challenging, members of the group focus solely on the practicalities of their exploration. They share their observations, negotiate over the phases of the expedition and their proper order, and speculate on the formation and width of the cave system. In the middle of this pragmatic discussion, the protagonist suddenly comes up with an anecdote she wants to share with the rest of the group:

"There was once a thinker, you know, who said that if you're not willing to find out what is and what has been within a ten-kilometer radius of your home, you're essentially an uneducated person, I say aloud. The thought springs to my mind suddenly - the way ideas always occur to me in the cave-and it seems important enough to be passed on."

"Did he mean those ten kilometers to be measured also underground?"

(Verronen, Luolavuodet 22) ${ }^{1}$

In this short conversation, the scales are tilted, figuratively speaking, in favor of a new understanding of human habitat, one that includes the underground environment, usually considered hostile and alien to human species. Moreover, the scene foregrounds the spatial aspect of human experience and presents the recognition of that aspect as a moral obligation. The final comment of the scene challenges the scales we use to measure and map our spatial experience. Our scales might be accurate, the speaker seems to suggest, but our use of them should always be open to critical examination and renegotiation.

In the field of literary studies, questions of scale have started to emerge along with the spatial turn and the onslaught of globalization, the Anthropocene, and other contemporary phenomena. Understanding scalar mismatches and synergies between the human and the nonhuman is a task in which the imaginative power of literature can prove its strength. As Michael Tavel Clarke and David Wittenberg argue in Scale in Literature and Culture: 


\section{Sarianna Kankkunen}

"humans' ineptitude in comprehending scale in the real world is likely the flipside of the tremendous ease with which we are able to rescale things in our imaginations" (3). What we lack in understanding can be compensated in our literary imagination.

The literary imagination needs forms to function, and as Ursula Heise claims, the forms of narration have started to change in order to "convey a more panoramic view" on the contemporary world of global environmental crises (55). In Imagining Extinction, Heise brings together Franco Moretti's conception of the modern epic and Lev Manovich's notion of database as an emerging cultural form, suggesting that environmental concern is more and more often expressed with different forms of enumeration: lists and catalogues accompanying narrative fiction, and outside the sphere of fiction, with biodiversity databases and Red Lists of endangered species. The problematics triggering these forms of enumeration are of scalar nature: according to Heise, classical narrative devices do not equip us with tools for grasping the magnitude of environmental threats. Strategies of enumeration, on the other hand, are a way of producing and expressing a numerical sublime, a sense of numbers and scales that transgresses everyday experience (see Heise 56).

This chapter focuses on how questions of scale are probed through a number of strategies, including enumeration, in Maarit Verronen's fiction. Verronen (1965) is a contemporary Finnish author whose works span three decades, more than twenty titles, and several modes from realism to allegory, fantasy, and dystopian fiction. She has gained a reputation as a novelist portraying onlookers and bystanders of society: people who seem to be more intimate with desolate places and natural phenomena than with the rest of humanity (see, e.g., Lehto; Majander). This links her with the tradition of Finnish literature, which has always cherished a close connection between human cultures and wilderness. As Pertti Lassila (1819) points out in his study on nature in Finnish literature, eminent literary historians, such as Viljo Tarkiainen (1879-1951), have emphasized the role nature and depictions of wilderness play in Finnish prose and poetry. The foundations for this reading of the Finnish literary tradition are inlaid in the nineteenth-century national epic Kalevala, which revived the magical and shamanistic world-view of the oral folk tradition, disseminating it for the purposes of nationalistic ideologies. But beside the shamanistic folk beliefs, Protestant Christianity played a role in cementing the role of nature in the Finnish literary tradition. As Lassila (28-30) notes, the roots can be traced back to the Baroque period, which was in the Finnish context the period of solemn, pious nature poetry instead of the more light-hearted bucolic poetry that took over Europe. Ideals of Enlightenment and Christianity fused and resulted in the so-called natural theology, which was one of the dominating features of Finnish literature well into the times of nationalist awakening (Lassila 30). In this tradition, the enumerative form emerges: lists of animals and plants are used as a way to praise the complexity and beauty of the 
godly creation (Lassila 31). This resonated with the oral folk tradition and its later adaptation, Kalevala: as Lassila (19) points out, the epic itself names and depicts multiple species accurately. In the epic, species of plants and animals are singled out in their particularity and simultaneously presented in the repetitive form of the Kalevala meter. All in all, both the pagan and the Christian traditions underlying Finnish culture emphasized the significance of nature and engaged with it through literary forms.

Looking at country statistics instead of the literary tradition, the presence of nature in Finnish literature has been further strengthened by societal structures: compared to other European countries, in Finland the process of urbanization started late, peaking in the 1960s. Today, Finland is the third most sparsely populated country in Europe (European Commission Eurostat: Population 2019). The influence of pagan folklore, the association between nature and the Finnish national identity, and the everyday reality where over 800,000 Finnish households (of a nation of 5.5 million) have access to a summer cottage typically set in the middle of nature, have all contributed to the fact that Finnish literature has been and still is interpreted in close relation to the realm of nature.

Maarit Verronen, with a professional background in natural sciences, moves beyond traditional nature writing and its logics of national symbols and opposing literary tropes, such as pastoralism and wilderness. She depicts the state of affairs of a late modern world, a world where the relationship between nonhuman nature and human cultures has to be renegotiated, a world of shifting scales. This chapter focuses on Verronen's novel Luolavuodet and another specimen of her prose fiction, Keihäslintu. As the caving scene quoted above suggests, Verronen's body of work depicts protagonists with a curious obsession with nonhuman environments and counterparts. I will start by exploring this obsession and linking it with the nineteenth-century concept of monomania. My main purpose is to analyze the tension between these two impulses: the need to focus, presented by the monomania, and the equally pressing urge to expand in order to comprehend nonhuman scales. After presenting the two novels and their monomaniacs, the chapter will then zoom in on the forms of enumeration both novels use to depict nonhuman scales. Since the forms of enumeration evoke a sense of sublime, I will relate it with the novels at hand and see how the struggle for representing the nonhuman-the struggle to expand the scale-is carried out in Luolavuodet.

\section{The Bird and the Caveman: Two Cases of Monomania}

Keihäslintu (2004, "The Spearbird") consists of independent short stories divided into two sections, Villi lintu ("Wild bird") and Sukupuutto ("Extinction"), and a third section titled "Keihäslintu [geirfugl; Pinguinus impennis]" ("Garefowl [geirfugl; Pinguinus impennis]"). In the third section, the fragments revolve around a single protagonist and her passion for the 


\section{Sarianna Kankkunen}

great auk, also known as the garefowl. The great auk is a species that went extinct over 150 years ago, mainly due to uncontrolled hunting. After seeing a stuffed specimen for the first time, the protagonist's obsession for the bird takes the form of an urge to travel around Europe from researcher to researcher and from one museum to another to see the remaining eggs and the preserved remnants of the great auk. She also takes the task of listing all the eggs and carries out thorough research on the fate of a mounted auk skin whose whereabouts are unknown. There is no practical reason for this enterprise, nor does she want one: it just happens that the bird has come to play a central part in her life.

Verronen's novel is a contemporary take on monomania, a concept introduced by early nineteenth-century psychiatrists, such as JeanneÉtienne Dominique Esquirol and Pierre Janet, and eagerly adopted by the French novelists. The symptoms of monomania, a preoccupation turning to a pathological obsession, may vary, but, as Marina van Zuylen remarks, "each one of its enactments is part of an abstract, autonomous desire to reorganize the world according to a long-lost model of wholeness" (Zuylen 5). Monomaniacs have "a love-hate relationship with permanence" (Zuylen 10); their obsessive interests are mental barriers against change, and their compulsive acts of examining and collecting are attempts to establish a stable state of affairs. These tendencies of monomania can be traced back to Freud's theories on melancholy, death drive and religious rituals, as for Freud, neurosis is a form of private religiosity (Zuylen 5). Freud draws a parallel between obsessive behavior and religious rites, claiming that the former is a distorted version of the latter: a pathological way to establish coherence where it is broken. In other words, as Zuylen $(5 ; 19)$ puts it, obsessive behavior is a way to grasp the absolute whenever it is threatened by change or flux. As Zuylen points out, the need to reinstate a former state of affairs is a key component of Freud's understanding of melancholia, but in Beyond the Pleasure Principle, this same drive or instinct appears as a central feature of the human-or even nonhuman-mind (Zuylen 13,19). In a highly contested (see, e.g., Smith; Weatherill) section of his study, Freud suggests that beyond all instincts and drives that function as catalysts for change, there exists an opposite drive: a drive for re-instituting an earlier condition, something what he poetically calls "the expression of inertia inherent in organic life" (Freud 30). Freud suggests that this inertia directs the organic towards inorganic, an attraction which eventually results in the death drive. "We are primarily great preservers, haters of change," Zuylen (13) writes and presents the subject's longing for stasis and immobility as the driving force behind monomaniac behavior.

The call of the inorganic is the key theme of the caving novel of Verronen. In Luolavuodet, it is the subterranean world of the caves that fixates the mind of the protagonist. In the novel, Vjeshta, the protagonist, measures up to the standards of an educated person presented earlier, for she carefully studies the surroundings of her new home. After relocating to 
a small town on the western coast of Finland, she memorizes the maps of the area, visits the local museum, hikes around her home, and delves into the archives of the town paper. These edifying activities have a hiddenor more precisely, buried-meaning. The protagonist has an obsessive interest: to go underground. She is a part-time caving enthusiast drawn to the area by her most recent discovery, a network of caves under the town. As the underground exploration progresses, the caves unfold a multitude of forgotten histories, both natural and cultural. But a richer and more nuanced relationship develops between the protagonist and the caves. In the course of the story, the protagonist spends nearly a decade digging and climbing, carrying out analyses of bat feces, taking geological measurements, and producing an ever-expanding map of the network of caves. Only then the underground world reveals its secrets. During these years, the protagonist abandons her academic work as mathematician, devotes most of her time to the study of the caves, and manages not only to rewrite the history of human settlement in the area but also to build a vivid network of specialists working around the caves.

The novel is a depiction of the strength and persistence of an obsession but also a description of the bond developing between a place and a person. The quest of mapping the cave turns into a process of developing self-awareness:

Mapping gives me pleasure. Explicit, finished maps of caves are beautiful. They are always incomplete-but that's an advantage, not a shortcoming. There's always a corridor extending beyond the edge of the map, heading to a place that's not visible. A place which I know nothing about. There's always more to find out; there's always more pleasure of finding and investigating.

I'm out of my depth while trying to explain this to someone else; rarely do I try. Most of the time, I have a feeling that people don't listen to me. The issue is too wide and large; it encompasses everything. Go ahead, try explaining the reasons for caving, while new reasons keep appearing and the old ones lose their meaning

$(\text { Luolavuodet } 53)^{2}$

In this passage, the protagonist has already embraced the states of uncertainty and incompleteness that are an essential part of any research project. The novel bears close resemblance to the post-structuralist criticism of maps and cartography as tools of power (see, e.g., Harley). The novel's approach to mapping is very different from the one depicted in the colonialist novel, especially Joseph Conrad's Heart of Darkness: instead of being steps towards dominance over something, these maps are meant to transform the subject itself, as they are tools for character formation. Instead of coloring the blank spots on the map, the protagonist keeps extending the map beyond the edge, already aware of the limits of her knowledge and power. Instead of a finished product, the process itself is the desired outcome. The 


\section{Sarianna Kankkunen}

passage draws a parallel between the unfinished, ever-expanding nature of the map and the protagonist's passion for mapping, which is "wide and large" and "encompasses everything." The nonhuman world is constantly changing and growing and so is human passion. Simultaneously, the passage sheds light on the monomaniac state of mind: the troubles the protagonist encounters in map-making are very similar to the ones she experiences in social contexts, but the monomaniac is willing to fight only on one front, while surrendering the other, namely, that of human interaction. By this I mean that in the case of the caves, the pathological preoccupation of mapping renders the challenges of scale and the difficulties of limitlessness into something tolerable, but in the social context, the strategy wavers, and the protagonist gives up the effort of explaining herself.

\section{Scaling Up, Scaling Down: Aesthetics of Restriction and Expansion}

In Verronen's Keihäslintu, the protagonist observes a preserved specimen of the great auk, a penguin-like, flightless alcid that became extinct in the nineteenth century:

Vladimir M. came back. He carried the bird. It was wonderful, incredibly beautiful. Black and white; lively eyes, a curious expression, a handsome, streamlined beak. Black back, little wings, head, neck, beak and flippers. ... She turned it around, took measures even. Sixty centimeters from tail to head, but because of the posture, the top of the head was fifty-five centimeters from the pedestal. The beak, eight centimeters, just like the flippers; the whole foot, fourteen. The diameters of the white spots on the head, four and two and a half centimeters.

"I love this bird"

$($ Keibäslintu 154)

In the scene, measurements taken from the mounted bird turn into an expression of its emotional significance: "I love this bird." The seemingly objective and external act of measuring evokes a response that is fully subjective, evaluative, and sentimental. The scene thus juxtaposes two possible approaches: rational and emotional, objective and subjective. Both approaches share the same agent; it is the measure-taker, Tanja, who utters the declaration of love for the bird. Her confession seems to suggest that it is not only the relevance of measurement that is questioned in this scene; the roles of the subject and the object are shifting. The bird, stuffed, mounted, and now measured, is the object of the scientific scrutiny. But it is actually Tanja, the subject of this examination, who is affected the most and of whom the narrated scene reveals the most. The scene illustrates an attempt to apply human scales to a nonhuman object. The result of this examination, a confession of love, is much more than a sudden burst of emotional release: 
engaging, physically and conceptually, with the nonhuman other, leads into an ethical stance. ${ }^{4}$ But as the scene demonstrates, this heightened selfunderstanding requires an embodied, physical contact as well as some sort of conceptual work with the nonhuman counterpart.

What about the formal aspects of this scene? The joyous, ecstatic testimony on the beauty of the bird almost turns into a report of its body parts and, later, their measurements. Sentences shorten, verbs disappear, and the narration takes the form of a list. First, the focalizer is blown away by the beauty of the bird, then, her attention is drawn to a smaller and smaller details of it. Aesthetic evaluations and emotional responses turn into a monotonous, detached listing of various measurements; the narrative form mimics the attentive consciousness of a monomaniac, whose obsessive concentration is a defense against emotional turmoil. The passage thus demonstrates how monomaniac behavior is linked with the need to organize and preserve: the protagonist's instant reaction to measure the body parts of the bird is an attempt to classify, categorize, and memorize the desired object.

In Luolavuodet, a similar kind of breathless account takes place when the narrator describes the caves:

Caves are filled with small eternities. How long did it take from the limestone to form from the shells and skeletons of animals in the bottom of the sea; how long did it take from the sea to withdraw, the land to rise into mountains, and wear out into hills; how long did it take from the water to erode those massive spaces! How long did it take from the calcite solution to precipitate into hard mineral in the dry air of the caves and to take the shape of stone curtains and pillars?

$(\text { Luolavuodet } 17)^{5}$

The repetition and the rhetorical question the narrator poses give the passage a lyrical, solemn tone. Nevertheless, the description is also a list that chronologically catalogs the stages of the cave formation in limestone bedrock. The description presents multiple scales and alternates between them: modest shells and skeletons make up masses of limestone; land turns into mountains and mountains into hills; soft water carves the hard stone and drops of calcite solution compose pillars of stone. The small composes the big, and the big is taken apart by the small. The enumerative form of the passage and the whole chapter is in accordance to this alternation: a list is a form of writing that directs one's attention simultaneously to the detail and the whole, demanding constant comparison between the two.

In both passages, the scales conflicts with the human experience. In the bird scene, the measurements taken are only a pale reflection of the emotional turmoil caused by the mounted bird. It is the beauty and the materiality of the bird that challenges human understanding. In the cave scene, the narrator lists question after question without any real attempt 


\section{Sarianna Kankkunen}

to answer them; the stages of the cave formation are represented only to highlight their unrepresentability. As for the caves, it is their spatiotemporality, their sheer volume of space, time, and matter, that exceed human imagination. As demonstrated by the two quotes above, in Verronen's novels, enumeration functions as a way to convey the disparity between the human subject and the nonhuman counterpart, be it a bird or a network of caves. As a literary form, enumeration also evokes the confusion the human agent experiences while confronting the nonhuman. A list is a demonstration of unwillingness to choose: as a multielement whole, a list is created by a reluctance, or incapability, to limit and focus. However, in the context of these two texts, the enumerative form can also be read as a sign of openness to various perspectives and as an attempt to avoid fixed viewpoints. Like a Cubist painting, a list as a form of literary description aims at describing multiplicities, simultaneities, and various viewpoints. In contemporary fiction, this may be one of the most effective ways to approach nonhuman counterparts. This is further enhanced by the fact that the list seems to convey truth value. It may be linked with what Roland Barthes calls the reality effect, the effect produced by the descriptive elements of the narrative or with our habit of associating lists in literature with their everyday counterparts, pragmatic lists, as Robert Belknap (5) calls them. In other words, the enumerative form might disrupt the plot, but it enhances the mimetic function of the literary text. In the case of Luolavuodet, the enumerative form is connected with the scientific description of a natural historical event, cave formation. The list simulates the discourses of natural science and historiography by imitating the collection and organization of data in these fields (see Young 15). Despite its openness and limitlessness, in Verronen's novels, the enumerative form introduces the epistemologies of science.

Lists, catalogues, and other forms of enumeration are an emerging strategy in fiction discussing the species extinction and environmental threat, claims Heise (61). In the already mentioned Imagining Extinction, she presents this "database aesthetic" as a possible, and even desirable, alternative to the elegiac mode more commonly found in extinction fiction. Catalogs and lists in the narrative evoke what she calls "a numerical sublime of sorts," a sense of numbers that is unattainable by more traditional narrative devices (Heise 56). The turn to the strategies of enumeration is a narratological-aesthetic reaction to the current status of the world's biodiversity loss, also known as the sixth mass extinction or the Holocene / Anthropocene extinction.

In literature and the arts, as Clarke and Wittenberg (4) note, the connection between human imagination and nonhuman scales has been typically discussed through the discourse of the sublime. The classic Kantian conception on the sublime emphasizes the transcendental nature of the experience: when facing a greatness too large to comprehend, the human subject is led to sense the limitations of their perception-and then, surpassing these limitations, to a state of recognition of their subjectivity, a 
state of supersensibility (Clarke and Wittenberg 4). Kant thus breaks away from the previous understandings of the sublime, which considered it the experience of being overcome; for him, it is precisely the subject's resistance against the act of being overpowered that becomes the core of the experience (Ryan 278).

In The Physiological Sublime: Burke's Critique of Reason (2001), Vanessa L. Ryan argues that the Kantian interpretation of the sublime has taken over both continental and English thought. According to Ryan, the key difference between the two sublimes, the Kantian and the Burkean, concerns the nature of the sublime experience: is the sublime experience located in the mind-or rather in the body? The Kantian conceptualization shifts the focus from the external object, the source of the sublime, to the perceiving and thinking mind. In Kant's formulation, the recognition of the superiority of the self over nature-the sublime experience-is also the source of moral feeling (Ryan 278-79). In contrast, Irish philosopher Edmund Burke's treatise A Philosophical Enquiry into the Sublime and Beautiful (1757) considers the physiological aspects of the experience, accentuating the physical affect and simultaneously reducing the role of the conscious mental activity sparked by the sublime (Ryan 270). This leads to a significantly different interpretation of the concept. According to Ryan, "The sublime for Burke is a question not of the subject's increasing self-awareness but of the subject's sense of limitation and of the ultimate value of that experience within a social and ethical context" (Ryan 266). For Burke, the sublime is the recognition of the limitations of the self, in other words, a sense of danger, which awakens the natural instinct for self-preservation. And most importantly: this new, heightened state of self-preservation and activity directs the subject towards sympathy for others. The sublime, for Burke, is the instinct of selfpreservation extended beyond the self and thus refined into moral actions (Ryan 277-78).

Verronen's novels present a highly interesting combination: a protagonist succumbing to the lures of monomania-that is, a depiction of the drive for constraint-together with a narrative device of enumeration-a narrative strategy evoking the sense of vast numbers. The first one aestheticizes restriction, the second one expansion. By juxtaposing these two, both novels foreground comprehension of spatial scales as well as shifts in scale. Nonhuman space, in this case, presents itself as a challenge for human cognition and imagination-but at the same time, this challenge is solved through a cultural-aesthetic mediation. The aesthetics are coupled with ethics: as demonstrated above, the emotional response to the presence of the nonhuman results in an ethical stance. In both novels, the monomaniac obsession that generates limitations and restrictions results in a sense of overcoming these very limitations. The key to this is the physical and spatial contact between the human subject and the nonhuman counterpart. These novels take a stance that resembles closely the Burkean sublime: the sublime that is bodily instead of mental, and physiological instead of intellectual, and 


\section{Sarianna Kankkunen}

produces a moral feeling (Ryan 277-79). In Keihäslintu, the encounter with the bird leads the protagonist to discuss her loss-the loss of the specieswith her husband. The couple mourns together. In Luolavuodet, the massive scale of the caves and their beauty motivates the nihilistic protagonist to share her findings with the local inhabitants-the map she's been crafting, turns out, can be a means of communication, she discovers. Verronen's narratives do not, however, renounce the rational and the intellectual: it is through the scientific work and measure-taking, through the obsession, that the protagonists are able to work their way to the sublime encounter.

\section{Losing a Sense of Proportion: Representing the Nonhuman}

Another case of overcoming limitations is presented in Verronen's caving novel. In the climactic scene of Luolavuodet, the protagonist is determined to finish the map of the caves she has been drafting. In order to do this, she has to venture to an unknown area of the caves, and there, in the heart of the labyrinthine cave system, a scene of wildly running animals, a tour de force of the Neolithic cave art waits for her: "The paintings have been assembled on the cave walls with skill and a careful eye for the formations of rock. They emerge from the stone, they are alive in the stone" (Luolavuodet 12526). ${ }^{6}$ The stone is turning alive, as the vivid images of reindeers, horses, and woolly rhinoceroses gallop to the protagonist's sight. Moreover, the stone is turning human: the scene blends culture with nature, as the nonhuman space shows its intertwining with an earlier human culture. The cave of the novel is presented as a canvas for the human imagination, a shift which emphasizes the role that activities of meaning-making play for the human spatial understanding. The rational quest for mapping the cave is contrasted with the expressive power of the images. Two forms of spatial meaningmaking, the rational and the artistic, or the material and the spiritual, come together.

While presenting his conceptions of the organic's yearning for inorganic, Freud leaned heavily on the nature philosophy of the German Romantics (McGrath). According to Schelling, nature seeks to become spirit and spirit seeks to become nature, a notion that captures the importance the Romantics gave to the idea of constant transformation and sublimation. In nature, the processes of transformation were especially visible in the world of minerals, which was interpreted as a middle realm between the organic and the inorganic. This philosophical doctrine was one of the reasons why the tropes of mine and cave became so central for the German Romantic literature. The mine, a source of precious metals, became a metaphor representing the shift from unconscious to conscious (Ziolkowski 30-32).

In the caving novel, it is not only the stones that turn human, since humans, too, turn into stone. After discovering the cave paintings, the protagonist continues her mapping journey and stumbles into a previously uncharted cave hall. 
The cave hall is almost round, its diameter is twenty meters. The ceiling rises to three meters and is bare of any paintings. The only vertical surface left blank is a calcite curtain of green and white, a beautiful set of petrified folds. It conceals a small recess that I can barely enter if I squeeze myself between the curtain and the painting of the horse.

I shine light on the recess before stepping in. I see a calcite bench, created by the drops falling from the cave ceiling, and on the bench, a dark bundle. The bundle is glazed by thin layers of translucent calcite.

The bundle is a child. A small, delicate child, curled up on her side.

It looks starving and cold. The stone cover over the child must have been formed rather quickly, for the corpse is well preserved: the clothes, the hair, everything is still there.

(Luolavuodet $125-26)^{7}$

The process of stratifying calcite solution which earlier in the narrative, while producing the cave pillars, triggered the protagonist's awe, has preserved the body of a Neolithic cave-dweller. Marvels of the underground world go hand-in-hand with the horrors; the eternities of the nonhuman scale that the caves conceal produce the utmost terror while conjoined with the human condition. Since the development of modern geology in the eighteenth century, caves have been seen as the archives of Earth's history, keepers of "deep time" (see, e.g., Ziolkowski chapter 2; Faflak). But, as Theodore Ziolkowski notes in his study of German Romanticism, already Antiquity and the Renaissance held the belief of the spelunca aevi, or the cavern of eternity. This notion of a specifically underground temporality, widely spread in German culture, was invigorated by the Romantics (Ziolkowski 34). The motif was treated by several authors from Johann Peter Hebel to E.T.A. Hoffman, especially after inspiration from an event in the Falun copper mines in Sweden, where the body of a miner gone missing in 1670 was found in 1719 in a perfect condition, preserved by a vitriol solution (Ziolkowski 53). Verronen's novel regenerates the Romantic motif and the alternation of organic and inorganic. The Romantic belief that inorganic minerals could turn into organic life-forms is represented by the girl turning into a calcite statue; the ancient idea of the cave as the place of deviant temporality is accompanied with the monomaniac's obsession for organizing and preserving the desired object.

This very obsession is at the same time questioned in the scene. At first, the protagonist takes great pains to map out the cave system, to preserve and organize a mass of lifeless stone; what she finds beneath it is a girl turned into stone. The narrative establishes an analogous relationship between the protagonist and the petrified corpse, and the monomaniac is reminded that the union between organic and inorganic might result in feelings of horror. This is, without a doubt, the culmination point of the novel: a moment in which the isolated, self-sufficient monomaniac faces her obsession, a symbolical presentation of the organic's yearning for the 


\section{Sarianna Kankkunen}

inorganic. The stone, which turned alive with the cave paintings, continues its transformation-but it is impossible to say to which direction. Is the calcite girl a symbol of death or a symbol of eternal life? The interpretation vacillates between these two poles and produces a sense of uncanny.

Verronen's contemporary take on the cave motif also modifies its content. Both the legend of the spelunca aevi and Hoffmann's famous novella The Mines of Falun (1819) entail an element of seduction and allure: the underground world tempts the human protagonist with delight and knowledge but in the end, brings nothing but "the sinful knowledge of sensuality, which leads to madness and death" (Ziolkowski 57). Verronen's novel, too, represents the cave as a place of knowledge-the girl, a member of a pre-glacial tribe living in the area, entered the cave to see the paintings the men of her tribe are working on, irritated by her exclusion of the painting ceremonies-but unlike the Romantic version of the motif, the novel doesn't eroticize the underground setting. The emphasis of the novel's cave metaphor is on different ways of knowing: the girl is drawn to the cave because of mythical-religious representations, and the protagonist feels the same temptation in the form of scientific interest, her speleological obsession. The girl is fascinated by the cave paintings representing wild animals, and the speleologist, on the other hand, is enchanted by the work of her own hands, a map of the cave network. They are both driven to danger because of their urge to perceive and represent something nonhuman: animals and their spirits, or the network of caves.

\section{Conclusion}

Verronen's monomaniac protagonists and their all-encompassing passions present simultaneously an analogy and an alternative to the dominant obsession of contemporary times, that of the profit-seeking and economic growth. In Keihäslintu, this is highlighted by the extinct bird, which was lost because of hunting. In Luolavuodet, the idea is even more pronounced, as one of the cave halls discovered by the protagonist tumbles down under a racetrack, the economic powerhouse of the whole region. In the character of a monomaniac, the novels present a critique of what is considered sane or reasonable. The monomaniac is always out of scale-but because of this, they are also more attuned to the nonhuman. The enumerative form, which is linked with the rationalist and scientific pursuits of the protagonists, offers an alternative to the ecomysticism, ecospirituality, and other forms of belief systems often offered as a solution to the crisis of the Anthropocene: aesthetics and empirical research, which make up the intellectual work, are still viable ways of meaning-making.

It would be unjust to suggest, however, that the monomaniac is the role model of the Anthropocene, the ideal human of the nonhuman era. They clearly are not. The monomaniac is a reflection of the isolated, hyperindividual subject: an atom among the others, adrift in the society, deprived 
of any meaningful interaction, lost in the light of their idée fixe. Hope, for them, comes in the form of physical, embodied contact with the nonhuman and the sublime experience, which connects them with their communities, again. The scalar shock of the sublime uncouples the obsessed, isolated mind; it doesn't undo the obsession, but it makes the subjects eager to share their experiences and seek the company of others who might view the world differently but are willing the listen, nevertheless. If these narratives have something to say, I suggest it is this: the encounter between the human and the nonhuman might be a solitary experience, but it has to be passed on to others.

\section{Notes}

1 “'Tiedätkö, eräs ajattelija on sanonut, että jokainen, joka ei halua tietää, mitä on ja on ollut kymmenen kilometrin säteellä hänen kodistaan, on perimmältään sivistymätön ihminen, sanon ääneen. Ajatus tulee mieleen yhtäkkiä-sillä tavalla kuin asioita aina tulee luolassa mieleen-ja se tuntuu riittävän tärkeältä eteenpäin kerrottavaksi.' 'Tarkoittiko hän sen kymmenen kilometriä mitattavaksi myös maan pinnan alapuolelle?" (Luolavuodet 22).

2 "Kartoittaminen tuottaa minulle nautintoa. Selkeät, valmiit luolakartat ovat kauniita. Ne ovat aina epätäydellisiä-mutta se on etu, ei puute. Aina jokin käytävä jatkuu kartan reunan yli jonnekin, jota ei enää kuvassa näy ja josta en tiedä mitään varmaa. On siis vielä lisää selvitettävää; vielä lisää nautintoa siitä, että jotakin löytyy ja selviää.

Sitä on vaikea selittää kenellekään ulkopuoliselle, enkä kovin usein edes yritä. Tavallisesti minulla on tunne siitä, ettei minua kuunnella. Koko asia on niin laaja; siihen sisältyy kaikki. Selitä nyt sitten, miksi tutkit luolia, kun koko ajan uusia syitä löytyy ja entiset menettävät merkitystään” (Luolavuodet 53).

3 "Vladimir M. palasi. Hän kantoi lintua. Se oli ihana, uskomattoman kaunis. Mustaa ja valkoista; eloisat silmät, utelias ilme, komea sulavalinjainen nokka. Musta selkä, pienet siivet, pää, kaula, nokka ja räpylät...Hän käänteli sitä, mittaili jopa. Kuusikymmentä senttiä pyrstöstä päähän, mutta asennosta johtuen päälaki oli viidenkymmenenviiden sentin korkeudella jalustasta. Nokka kahdeksan senttiä, samoin räpylät; koko jalka neljätoista. Pään valkoisten laikkujen halkaisijat neljä ja kaksi ja puoli senttiä. 'Rakastan tätä lintua'” (Keihäslintu 154).

4 As philosophy of emotions, led primarily by Martha Nussbaum, has claimed, emotions are not just impulses but "intelligent responses to the perception of value" (Nussbaum 1).

5 "Luolat ovat täynnä pieniä ikuisuuksia. Kuinka kauan onkaan mennyt siihen kun kalkkikivi on muodostunut eläinten tukirangoissa meren pohjassa; siihen kun meri on väistynyt ja maa kohonnut vuoriksi ja kulunut kukkuloiksi; siihen kun vesi on syövyttänyt kiveen nuo valtavat tilat! Tai siihen kun veteen liuennut kalsiitti on kuivassa luolailmassa saostunut kovaksi mineraaliksi ja muodostanut kiviverhoja ja-pylväitä?” (Luolavuodet 17).

6 "Maalaukset on sijoitettu paikalleen luonnollisesti, aivan kuin ne olisivat syntyneet seinän kivestä, eläisivät siitä ja olisivat osa sitä” (Luolavuodet 12526).

7 “Sali on miltei pyöreä, läpimitaltaan parikymmentä metriä. Katto on runsaan kolmen metrin korkeudella; siinä ei ole maalauksia. Ainoa laaja maalaamaton pystysuora pinta on kaunis valkovihreä kalsiittiverho jähmettyneine 


\section{Sarianna Kankkunen}

laskoksineen. Se kätkee taakseen pienen komeron, jonne voi pujahtaa seinän vieritse, hevosenkuvan ohi.

Valaisen komeroa ennen kuin astun sinne. Näen kalsiittipenkin, jonka katosta putoilleet pisarat ovat synnyttäneet, ja penkillä tumman mytyn, jonka läpikuultava kalsiitti on peittänyt kokonaan, ohuesti.

Mytty on pieni ja hento kyljelleen käpertynyt lapsi.

Se näyttää nälkiintyneeltä ja palelevalta. Kattavan kivikuoren on täytynyt muodostua lapsen päälle hyvin nopeasti, sillä ruumis on säilynyt hyvin, vaatteineen, hiuksineen, kaikkineen" (Luolavuodet 125-26).

\section{References}

Belknap, Robert E. The List: The Uses and Pleasures of Cataloguing. Yale University Press, 2004.

Burke, Edmund. A Philosophical Enquiry into the Sublime and Beautiful. Routledge Classics, 2008.

Clarke, Michael Tavel, and David Wittenberg. "Introduction." Scale in Literature and Culture, edited by Michael Tavel Clarke, Michael Tavel, and David Wittenberg, Springer, 2017, pp. 1-25.

Conrad, Joseph. Heart of Darkness. Penguin, 1994.

European Commission. Eurostat: Population 2019.Demo_R_D3DENS. Updated 15.3.2021. Accessed 8.6.2021.

Faflak, Joel. "Introduction." Marking Time: Romanticism and Evolution, edited by Joel Faflak, University of Toronto Press, 2017, pp. 3-25.

Freud, Sigmund. Beyond the Pleasure Principle. Translated by James Stratchey, Norton, 1975.

Harley, J. B. "Deconstructin the Map." Cartographica: The International Journal for Geographic Information and Geovisualization, vol. 26, no. 2, 1989, pp. 1-20.

Heise, Ursula. Imagining Extinction: The Cultural Meanings of Endangered Species. University of Chicago Press, 2016.

Lassila, Pertti. Metsän autuus. Luonto suomalaisessa kirjallisuudessa 1700-1950. Suomalaisen Kirjallisuuden Seura, 2011.

Lehto, Silene. "Maarit Verronen-oman tiensä kulkija." Kirjasampo.Fi, January 2012, https://www.kirjasampo.fi/fi/node/310.

Majander, Antti. "Liikettä oivalluksen tähden. Maarit Verronen ei ujostele humanistisuutta.” Helsingin Sanomat, 13 December 1996, https://www.hs.fi/ku lttuuri/art-2000003584506.html.

Manovich, Lev. The Language of New Media. MIT Press, 2001.

McGrath, S. J. "Is Schelling's Nature-Philosophy Freudian?” Analecta Hermeneutica, vol. 3, 2011, pp. 1-20.

Moretti, Franco. Modern Epic: The World-System from Goethe to García Márquez. Translated by Quentin Hoare, Verso, 1996.

Nussbaum, Martha C. Upheavals of Thought: The Intelligence of Emotions. Cambridge University Press, 2003.

Ryan, Vanessa L. "The Physiological Sublime: Burke's Critique of Reason.” Journal of the History of Ideas, vol. 62, no. 2, 2001, pp. 265-279.

Smith, Mr Robert Rowland. Death-Drive. Edinburgh University Press, 2010.

Verronen, Maarit. Keihäslintu. Tammi, 2004.

Verronen, Maarit. Luolavuodet. Kirjayhtymä, 1998. 
Weatherill, Rob, editor. The Death Drive: New Life for a Dead Subject? Rebus Press, 1999.

Young, Liam Cole. List Cultures: Knowledge and Poetics from Mesopotamia to BuzzFeed. Amsterdam University Press, 2017.

Ziolkowski, Theodore. German Romanticism and Its Institutions. Princeton University Press, 1990.

Zuylen, Marina. Monomania: The Flight from Everyday Life in Literature and Art. Cornell University Press, 2005. 